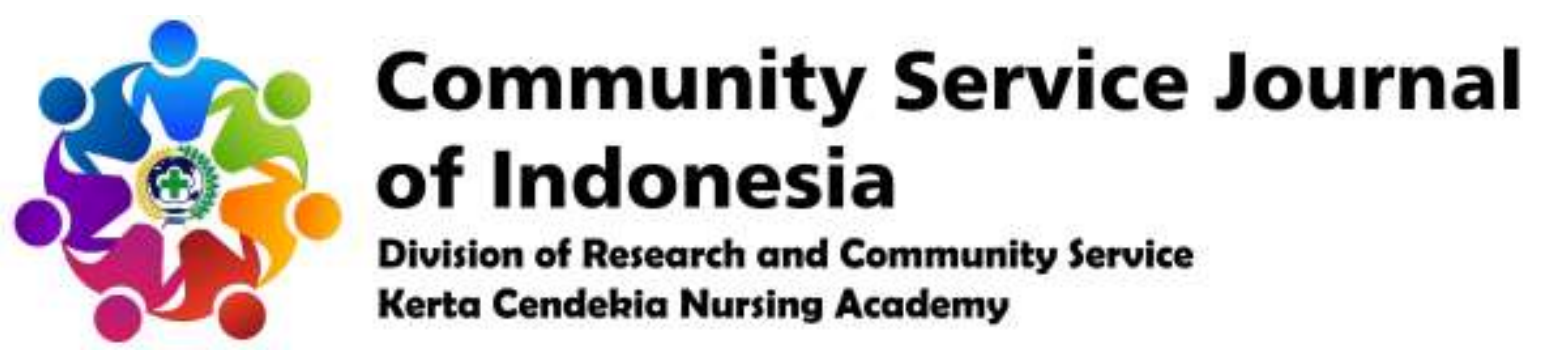

https://ejournal-kertacendekia.id/index.php/csji/index

Community Service Journal of Indonesia 3 (1) (2021): 4-7

Doi: https://doi.org/10.36720/csji.v3i1.285

\title{
IMPROVED KNOWLEDGE OF YOUTH RELATED TO ANEMIA
}

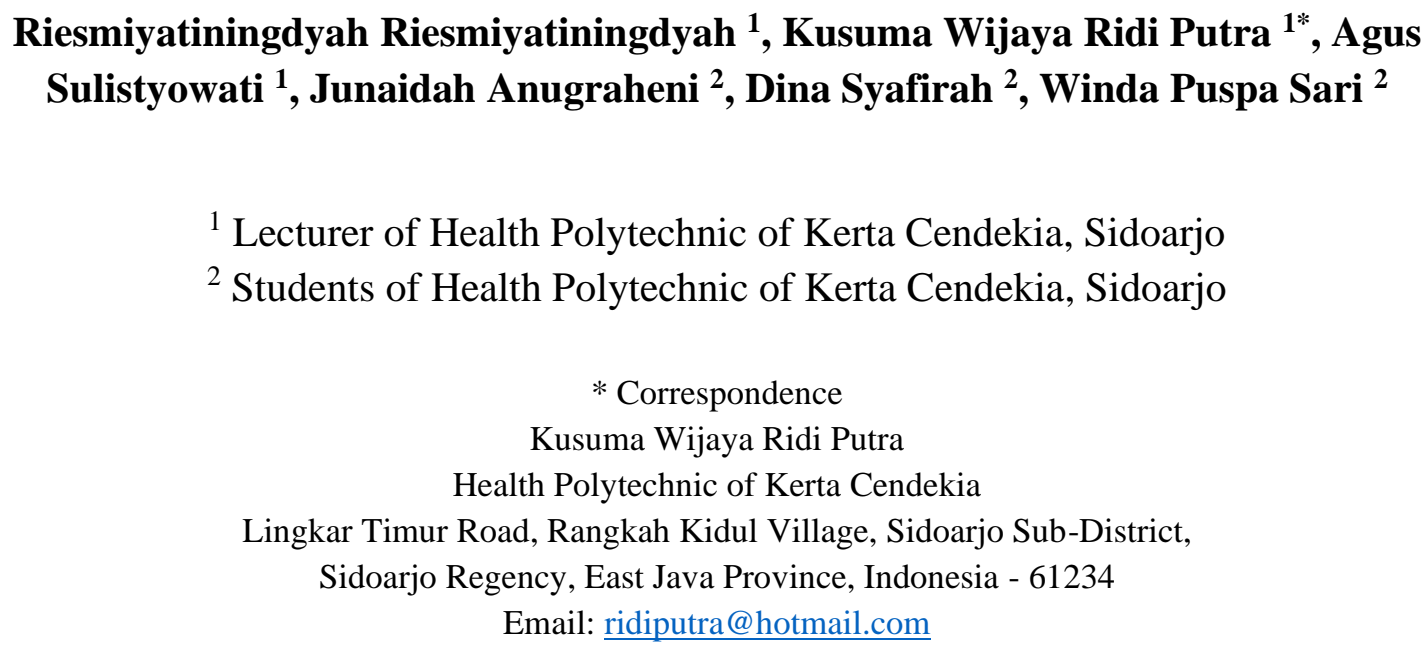

\begin{abstract}
Health promotion activities about anemia in adolescents at the Islamic Boarding School of Tahfidz Putri Hidayatullah, Sidoarjo are a form of community service in the form of counseling aimed at increasing the knowledge of young women about anemia that often appears in adolescents. The activity will be held on March 28, 2021 at the Islamic Boarding School of Tahfidz Putri Hidayatullah, Sidoarjo. The target is young women who are female students at the Islamic Boarding School of Tahfidz Putri Hidayatullah, Sidoarjo. Prior to the implementation of these activities, there is a process of preparing activities for approximately 3 weeks before the activities are carried out, starting from determining the theme of the extension to applying for permits to the relevant parties. As a form of evaluation, the activity was attended by 24 female students and 1 boarding teacher/caregiver, the participants participated in the activity happily and looked very enthusiastic, health promotion activities could run on time and smoothly.
\end{abstract}

Keywords: Anemia, youth, knowledge, health promotion.

(C) 2021 The Authors. Community Service Journal of Indonesia Published by Institute for Research and Community Service, Health Polytechnic of Kerta Cendekia, Sidoarjo

This is an Open Access Article distributed under the terms of the Creative Commons Attribution 4.0 International License which permits unrestricted non-commercial use, distribution, and reproduction in any medium, provided the original work is properly cited.

E-ISSN

2684-7884

P-ISSN

2774-4027 


\section{INTRODUCTION}

Adolescents have a high risk of anemia, especially iron nutritional anemia. This happens because adolescence requires higher nutrients including iron for growth and development its development. Young women have a higher risk than young men, this is because young women experience menstruation (menstruation) every month. In addition, young women tend to be very concerned about their body shape so that they will limit their food intake and many restrictions on food such as dieting vegetarian.

The impact of the incidence of anemia in adolescents can reduce concentration and learning achievement, as well as affect productivity among adolescents. Besides that, it can also reduce the body's resistance so that it is easy to get infections. Anemia can affect a person's level of physical fitness. As a result of long-term iron deficiency anemia in young women who will later become pregnant, these young women are unable to meet the nutritional requirements for themselves and their fetuses, thereby increasing the risk of maternal death, prematurity, LBW (Low Birth Weight), and perinatal death.

\section{OBJECTIVES}

General Purpose

After 40 minutes of health education, it is hoped that the female students at the Islamic Boarding School of Tahfidz Putri Hidayatullah, Sidoarjo, can understand anemia in adolescents.

\section{Special Purpose}

After 40 minutes of health education, it is hoped that the female students at the Tahfidz Islamic Boarding School, Hidayatullah Sidoarjo, can understand related to:
1. The meaning of anemia.

2. The causes of anemia.

3. The symptoms of anemia.

4. The prevention of anemia.

5. The cure for anemia.

\section{PLAN OF ACTION}

Strategy Plan

The strategy plan implemented, including:

1. Coordinate with the caregivers of the Islamic Boarding School of Tahfidz Putri Hidayatullah, Sidoarjo to apply for permission to carry out health education as a nursing program and to help provide useful knowledge for the Islamic Boarding School of Tahfidz Putri Hidayatullah, Sidoarjo.

2. Establish a time contract with the Islamic Boarding School of Tahfidz Putri Hidayatullah, Sidoarjo.

3. Providing health education to the community at large.

\section{Implementation}

Actions taken in the implementation of these activities, including:

1. Contacting the caretaker of the Islamic Boarding School of Tahfidz Putri Hidayatullah, Sidoarjo, to request permission to carry out the activity and to gather the female students.

2. Prepare a place and media for counseling.

3. Delivering material to female students of the Islamic Boarding School of Tahfidz Putri Hidayatullah, Sidoarjo.

\section{Setting}

This health promotion activity was carried out at the Islamic Boarding School of Tahfidz Putri Hidayatullah, Sidoarjo on March 28, 2021. 
Target

The target of the implementation of this health promotion is young women who are in the Islamic Boarding School of Tahfidz Putri Hidayatullah, Sidoarjo on March 28, 2021.

\section{RESULTS AND DISCUSSION}

This activity was carried out on March 28, 2021 starting at $15.30 \mathrm{WIB}$ and ending at $16.45 \mathrm{WIB}$, the counseling time was according to the plan. The activity was carried out at the Islamic Boarding School of Tahfidz Putri Hidayatullah, Sidoarjo. There were 24 participants in attendance with 1 boarding housekeeper. Participants seemed conducive in the process of delivering the material. Activities in the form of health education, giving leaflets, discussions, questions and answers, and demonstrations. The equipment used during the counseling process is a laptop, Powerpoint, video, leaflet, LCD, and poster. The management of the Islamic boarding school is willing to cooperate in the implementation of this health promotion activity. The participants who attended seemed enthusiastic and no one left the room before the event was over. The evaluation of this activity was assessed through a questionnaire distributed to health promotion participants. The results of the evaluation showed that $90 \%$ of participants could mention the definition of anemia, $90 \%$ of participants could mention the causes of anemia, $70 \%$ of participants could mention the symptoms of anemia, 95\% of participants could mention anemia prevention, and $95 \%$ of participants could mention anemia treatment.

\section{CONCLUSION}

Health education activities associated with anemia to adolescent girls will help them to overcome the problems caused by anemia, so that their development will be maintained properly.

\section{REFERENCES}

-----. (2019). Anemia. Retrieved from https://www.mayoclinic.org/diseas es-conditions/anemia/symptomscauses/syc-20351360.

Basith, A., Agustina, R., \& Diani, N. (2017). Faktor-faktor yang berhubungan dengan kejadian anemia pada remaja putri. Dunia Keperawatan: Jurnal Keperawatan Dan Kesehatan, 5(1), 1-10.

Fadli, Rizal. (2021). Anemia. Retrieved from

https://www.halodoc.com/kesehata n/anemia.

Fadila, I., \& Kurniawati, H. (2018). Upaya Pencegahan Anemia pada Remaja Puteri sebagai Pilar Menuju Peningkatan Kesehatan Ibu. In Prosiding Seminar Nasional FMIPAUT (pp. 78-89).

Putra, K.W.R., Riesmiyatiningdyah, R., \& Sulistyowati, A. (2021). Reliability of Modification Questionnaire of Knowledge Level about Anemia in Adolescent. Nurse and Holistic Care, 1 (1), 1-6.

Riesmiyatiningdyah, R., Putra, K.W.R., \& Sulistyowati, A. (2021). The Effect of Health Education on Adolescent Knowledge about Anemia. Nurse and Health: Jurnal Keperawatan, 10 (1), 59-64.

Willy, Tjin. (2019). Anemia. Retrieved from

https://www.alodokter.com/anemia

Zulaekah, S. (2007). EFEK
SUPLEMENTASI BESI, VITAMIN C DAN PENDIDIKAN GIZI TERHADAP PERUBAHAN KADAR 
HEMOGLOBIN ANAK SEKOLAH

DASAR YANG ANEMIA DI

KECAMATAN KARTASURA

KABUPATEN SUKOHARJO THE

EFFECT OF IRON, VITAMIN $C$

SUPPLEMENTATION, AND

NUTRITION EDUCATION ON THE

INCREASE OF $H$. Program Pasca

Sarjana Universitas Diponegoro. 